\title{
Communing With Darwish's Ghosts:
}

\section{Absent Presence in Dialogue With the Palestinian Moving Image}

Anna Ball

Senior Lecturer, Department of English, Cultural and Media Studies, Nottingham Trent University anna.ball@,ntu.ac.uk

Post-peer review, pre-publication version. Published version available in Middle East Journal of Culture and Communication 7 (2014), pp.135-151.

[Abstract: In his prose-poem Absent Presence (published in English translation in 2010), the revered Palestinian poet Mahmoud Darwish identified a source of tension that resonates through much Palestinian creative expression: a tension not between Arab and Jew, nor between Israeli and Palestinian but between presence and absence. Drawing on the many motifs of presence and absence, and by extension, of visibility and invisibility, spectrality and haunting that surface within Absent Presence, this article seeks to translate Darwish's poetic meditations into a visual context by placing his work in dialogue with two pieces of Palestinian video art, Sharif Waked's To Be Continued... (2009) and Wafaa Yasin's The Imaginary Houses of Palestine (2010), which share Darwish's preoccupation with ideas of the spectral, and of present-day Palestine's complex relationship with its past. Mobilising a range of critical concepts including Abu-Lughod's theorisations of 'postmemory' and Derrida's notion of 'the spectral', this article explores the ways in which various forms of absence arising from Palestine's fraught national history continue to haunt contemporary Palestinian video art, while arguing that the presence of the 'spectral' within such works also reveals a vibrant creative present in motion.]

[Keywords: Mahmoud Darwish, Wafaa Yasin, Sharif Waked, spectral, video art, Absent Presence] It is impossible to venture very far into the rich territories of Palestinian film and video art without finding that certain images come to occupy a haunting presence in one's own imagination. Perhaps it 
is the languorous shot of the slow, winding caress of fingers and hands between ES and his lover in Divine Intervention (2002) that lingers on in the darkness of the cinema after departing from the screen; or perhaps the sight of a young girl living in the Shatila refugee camp opening an envelope from her pen-friend in the West Bank, only to find that it is full of soil from the village from which her family were expelled three generations ago: one of the many astonishing sights witnessed in Mai Masri's documentary Frontiers of Dreams and Fears (2001). Yet it is not only filmmakers and viewers of Palestinian visual culture who find themselves pursued by haunting images. As the late, great poet Mahmoud Darwish demonstrated in an extraordinary and somewhat unclassifiable literary work called Absent Presence, the poetic imagination is also alive with ghosts - or, to put it more specifically, is inhabited by images of a spectral Palestinian past that refuses to be laid to rest:

Nostalgia is the groaning of rights which cannot produce proof of the power of rights in the face of the rights of persistent power. The groaning of houses buried beneath the settlements, which the absent bequeaths to the absent, the present to the absent, with the first drop of milk $[\ldots]$ Nostalgia is the sound of silk rising from the mulberry to the one who is nostalgic for it, in an exchange of groans. (Darwish 2010: 85)

How could one fail to be haunted by such lines? Rights, literally human ones, that groan, like the subject of a premature burial; homes whose erasure aches within the body to the extent that it is expelled through the very milk of the mother's body; and that surprising sensuousness, even eroticism of the silkworm-laden mulberry whose delicate threads intertwine so intimately with the nostalgic subject as to produce an exchange of groans. Yet the ghosts that rise from Darwish's text are more than simply haunting images: they are also the spectres of Palestine's deeply traumatic history and traumatised national consciousness, which surface as a dialectical interplay between visibility and invisibility, presence and absence in Darwish's imagination. The highly imagistic nature of the spectral Palestine in Darwish's Absent Presence seems to incite ready conversations with recent works of Palestinian video art by Sharif Waked and Wafaa Yasin, in which the fraught 
relationship between presence and absence, visibility and invisibility, past and present is also at stake. By placing these works in dialogue with Absent Presence - allowing them to commune with Darwish's ghosts, as it were - this article seeks to explore the complex visuality and visibility of Palestine's past within the present, and to reveal how the Palestinian moving image is animated by the presence of the spectral.

Darwish himself has come to assume a 'symbolic capital...so immense' (Antoon 2008: 4) that he occupies the position of 'national poet' in the Palestinian creative canon. Born in 1942 in the village of Al-Birweh in the Galilee and forced to flee to Lebanon with his family during the Nakba of $1948,{ }^{1}$ Darwish assumed a nomadic existence for much of his life, spending time in Moscow, Cairo, Beirut, Cyprus and Paris, before eventually settling in Ramallah, where he died in 2008, his passing marked by three days of national mourning and a State funeral. Having risen to fame in his late teenage years for poems full of resistant national sentiment (most famously, 'Identity Card', Darwish 1980: 10-11), Darwish's later work underwent a transition in the 1990s, when he surprised his audience by publishing a volume of love poetry, The Stranger's Bed (selections of which remain in print in Darwish 2007: 5-120) as a consolidation of the shift from lyrical to symbolic and abstract concerns, and from a primarily political to more personal voice that had been developing within his work for some decades (Shehadeh 2002: 54). Such a shift led to a crisis of interpretation for many critics, who struggled to reconcile his roles as 'the Palestinian national poet and as a poet of human "universals"” with one another (Bernard and Elmarsafy 2012: 2). ${ }^{2}$ As Saif al-Rahbi recognises,

\footnotetext{
${ }^{1} 1948$ saw the foundation of the State of Israel and the consequent production of over 750,000 Palestinian refugees. Its catastrophic effects on the Palestinian population and nation, which included the erasure of historical Palestine and some 500 towns and villages from the map, means that it is viewed as a key site of historical trauma for Palestinians, many of whom have never been able to return to their homeland. (See Masalha 2012: 2)

${ }^{2}$ Darwish's work has invited extensive critical interest, but it is significant to note that the vast majority of Darwish criticism focuses on questions of nationhood, exile and land within his work (see for example Alshaer 2013: 257-283 and Ahmed et.al. 2012), though Bernard and Elmarsafy (2012) also emphasize the possibility of reading Darwish as a 'love poet', a term Darwish sometimes used to describe himself. Within this article, I explore the possibility of a symbiotic interpretation of the political and personal, exterior and interior, through the use of a psychoanalytic framework inflected with the 'worldly' attentiveness of postcolonial theory: an approach posited by an increasing number of critics who suggest that while 'trauma provides the best framework for thinking about the legacies of violence in the colonized/postcolonial world' (Rothberg 2008: 226), 'trauma theory's foundation in Freudian psychoanalysis may be acknowledged as a point of departure [but one] that invites further expansion...towards non-western, non-Eurocentric models of psychic disorder and of reception and reading processes' (Visser 2011: 280). In my attempt to engage such a strategy, I drawn directly upon Lila Abu-Lughod's application of psychoanalytic 'trauma theory' to both her own familial narratives of the Nakba, and the Palestinian context more broadly as a route into own interpretation of Darwish, Waked and Yasin's works. Thus I would suggest that although the motifs of spectrality, haunting, regression and apparition at play in this article clearly have their origins in so-called 'western' trauma theory, they undertake a process of travel and
} 
however, two recurrent themes resonate across both the political and personal streams of Darwish's work: those of 'absence and death' (al-Rahbi 2008: 60). While this traumatic undercurrent assumes a deeply personal poignancy in his long poem 'Mural' (which he composed during serious illness in 1999 in preparation for his own death), it also emerges as a more fundamental 'core of...existence' and experience within Darwish's work, on whom 'absence stamped its mark...from early childhood' in the same way that the 'stunning absence of homeland...mark[ed] an entire generation of Arabs' (al-Rahbi 2008: 61). Thus absence and its constant struggle with presence becomes a site at which collective and individual, exterior and interior worlds collide and assume an absolute interconnectedness within Darwish's poetry. Nowhere does this emerge with greater clarity than in one of his last works, Absent Presence (originally published in Arabic as as Fî̀ Hadrat Al-Ghiyâb in 2006), an 'autobiographical' prose-poem composed just two years before his death in which he both re-confronts those previous premonitions of his passing, and resurrects his memories of a life lived in the simultaneous presence and absence of Palestine.

It is hardly surprising that Darwish should be so haunted by questions of presence and absence, given the sense in which these dynamics haunt the very core of Palestine's collective national psyche. From the inception of European and Zionist interests in Palestine, which culminated in the Nakba ('catastrophe') of 1948, narratives of colonial dominance have systematically sought to erase the Palestinian nation and its people from the map, and from cultural consciousness. Tropes of absence reveal themselves in both the Zionist founding myth of Palestine as 'a land without a people for a people without a land' (Said 1992: 9), and in Golda Meir's infamous declaration that

It is not as though there was a Palestinian people in Palestine considering itself as a Palestinian people and we came and threw them out and took their country away from them. They did not exist. (Meir 1969: 12) 
In Absent Presence, Darwish vividly evokes the existential crisis engendered by the Zionist imagination for 'the people who should not have existed in the Promised Land' (2010: 47), the Palestinians, who find that 'a man who was born in a country which does not exist does not exist either...you are nowhere....Nowhere is exile' (2010: 35). As Said sums it up, 'the question of Palestine is therefore the contest between an affirmation and a denial [...] a struggle between a presence and an interpretation' (1992: 8). Yet such ideological challenges to Palestinian presence have been rendered concrete over the years through Israeli policies such as the continued denial of the 'right of return' to Palestinians (see Hanafi 2002); in the production of the surreal category of the 'present absentee': a condition with which Darwish himself was only too familiar; ${ }^{3}$ through the strategies of apartheid and ghettoisation enacted by the Occupation, such as the use of checkpoints, road systems and walls designed to contain and conceal the presence of the Palestinian population; and through continual attempts to place limits upon Palestinian cultural production and its international dissemination (see Jacir 2006). Thus Palestinian national and, by extension, creative consciousness cannot help but remain deeply aware of the drive towards absence and erasure that accompanies their enduring presence. As Dabashi puts it: 'at the core of the Palestinian historical presence is... a geographical absence [and] the overriding presence of an absence is at the creative core of Palestinian cinema' (2006: 10).

As Dabashi's quotation also suggests, though, this enduring absence refuses simply to connote lack within the Palestinian imagination. Rather, the repetitive cycle of traumas associated with such absence - traumas that, as Lena Jayyusi notes, would come to recast the Nakba 'not [as] the last collective site of trauma [...] but as the foundational station in an unfolding and continual saga of dispossessions and erasure' (2007: 110) - gives rise to repeated visualisations of a lost Palestine that seem to affirm Freud's theorisation of trauma as an unresolved event that continues to surface in the (here, collective as well as individual) psyche 'like an unlaid ghost' (Freud 1909: 122). As Darwish puts it in Absent Presence, 'Aeroplanes chase the ghost in the air; tanks chase the ghost

\footnotetext{
${ }^{3}$ The term 'present absentee' is the product of the Absentee Property Laws passed by Israel in 1950. It describes Palestinians who were absent from their properties during the Nakba of 1948, and thus had their properties confiscated, but who nevertheless remained in Israel, without a home (Schechla 2001). Darwish's family were forced to flee from their village during the Nakba and when they returned to the Acre area a year later, they were thus designated 'present absentees' (Shaheen, 'Introduction' to Darwish 2010: vii).
} 
on the ground; submarines chase the ghost in the sea, but the ghost expands' (2010: 47): the continual desire to erase the Palestinian presence also invokes a spirit of powerful, enduring presence in the Palestinian people; a presence that materialises in many ways - through community, through political solidarity, through resistance, and also through cultural expression, which collectively seek 'reclamation, a restoration of something lost [...] a writing back into history of what has been deliberately erased' (Hamdi 2011: 23-24). The absences that present themselves in Darwish's poetic imagination, then, are more than just lonely spectres who refuse to be exorcised: they are phantoms of an unfinished past seeking acknowledgement, even retribution through their visual presence. What, then, might Darwish's ghosts have to say when allowed to commune with works of contemporary video art?

Placing Darwish's Absent Presence in dialogue with recent works of Palestinian video art is perhaps not as unusual a move as it might at first appear. ${ }^{4}$ While Darwish has been described as 'the voice of Palestine' (Hamdi 2012: 31), both his visibility as Palestine's national poet and the potent visual imagery within his work have been central to his presentation within Palestinian national consciousness. Darwish himself was no stranger to the screen: in 1998, he was the subject of Simone Bitton's documentary, As the Land is the Language; in 2004, he was featured in Godard's film Notre Musique and his poetry has also served as a conscious point of inspiration for a number of recent film directors and video artists. ${ }^{5}$ Absent Presence, meanwhile, displays a consciously visual preoccupation with what Darwish terms 'the aesthetics of language' (2010: back cover): those sensuous, tangible qualities to words that make themselves visible in the mind's eye, while within the text itself, Darwish's own sense of existential estrangement from his 'presence' as a Palestinian is evoked through the motif of the cinema screen, on which 'you [see] yourself in a long reel of film slowly

\footnotetext{
${ }^{4}$ It is worth noting that this article arises from an exhibition of short film and video art that I curated at the Bonington Gallery at Nottingham Trent University, UK, in September 2013. This exhibition, 'Presenting Absence: Moving Images of Palestine', employed Darwish's Absent Presence as a conceptual starting-point for considering the absence/presence, visibility/invisibility dialectic in a range of work about Palestine by both Palestinian and non-Palestinian directors/artists, and included short films by Omar Al-Qattan and Sarah Wood, and video art by Larissa Sansour, Sama Alshaibi, Katarina Skjonsberg and Therese Olson, and Basel Abbas and Ruanne Abou Rahme, in addition to the artists discussed within this article.

${ }^{5}$ The 2012 film Two Metres of This Land, by the Spanish-Palestinian director Ahmad Natche, is inspired by Darwish's poem 'Mural' and is set near to his tomb in Ramallah, while Dia' al Azzeh's four-minute work of video art Motionless Weight (2009) follows the flight of a plastic bag from Darwish's grave to a Ramallah garbage dump, including past a wall bearing an image of Darwish.
} 
telling what had happened to your people, robbed of their tongue, their wheat, their house, their evidence' (2010: 36). Yet its unusually meditative prose (or narrative poetry) allies it to video art in a special way. While the work has been variously described as a work of autobiography, as a prosepoem and as self-elegy, Darwish himself stated that 'I do not know to which literary genre this book belongs...It is not entirely verse or entirely prose...not autobiography, nor... an ordinary sort of novel' (2010: back cover). Arguably, the ambivalent, liminal genre of Darwish's work echoes the very nature of video art, which, as Bashir Makhoul writes in his groundbreaking collection on the subject, is itself a highly transitional genre, 'a medium made for negotiating borders', which has become 'more mobile, diffuse and widely disseminated' than any other visual medium, due in no small part to the readiness of its transition and transmission via online technologies (Makhoul 2013: 24; xvi). As a medium that sits part-way between the technical demands of narrative filmmaking and that is also receptive to the abstract, conceptual, primarily non-narrative language of artistic representation, video art (like Darwish's own prose-poetry) often retains a consciousness of its liminal positioning between the fictional and non-fictional, seeking to at once exploit and reject its function as visual documentation (Magagnolio 2011: 311-324) and thus raising intriguing questions about how to read the images it presents: as a documentation of visual 'truth' and reality, or as a language of the poetic imagination. It is perhaps this very intermediality, even liminality that makes video art such an apt medium for the representation of Palestine's ambivalent visual presence. Indeed, as Said writes, 'since the main features of our present existence [as Palestinians] are dispossession, dispersion, and yet also a kind of power incommensurate with our stateless exile, I believe that essentially unconventional, hybrid, and fragmentary forms of expression should represent us' (Said 1986: 6): a statement that seems to assert the possibility of a radical creative presence simultaneously within, of and in defiance of the very condition of absence. If Darwish's prose-poetry offers one such manifestation of a radical presence through the language of absence then video art arguably presents another - yet in the work of the artist Sharif Waked, this presentation of absence assumes an altogether more unexpected and provocative form. 
Waked is now firmly established as a leading figure within the field of Palestinian video art, his work having been exhibited at numerous international biennials, museums and galleries and residing in a number of permanent collections, including at the Guggenheim, New York. Born in 1964 in Nazareth, he continues to live and work in Nazareth and in Haifa, where he studied Art and Philosophy at university. As an artist, Waked utilizes a variety of mediums ranging from computergenerated graphics (Jericho First, 2002) to site-specific sculptural installation (Khumus, 2008) but it is his video work that has attracted the most critical attention, notably his 2003 work Chic Point - a seven-minute film in which young Palestinian men parade down the catwalk, showcasing a collection of 'the latest in checkpoint fashion': garments designed to enable quick stripping and bodily exposure at the command of the Israeli checkpoint authorities (Hochberg 2010: 578). This work is typical of the subversive humour with which Waked often seeks to reveal the absurdities and injustices of life for Palestinians. Yet in his 41-minute video performance piece To Be Continued... (2009, produced by and premiered at the ninth Sharjah Biennial, UAE), his satirical visualisation of Palestine operates not simply through playful and satirical presentation, but also through a deeply poetic language of potential erasure and absence.

Just as Absent Presence begins with the poet poised at the cusp of mortality, ready to set off to his 'appointment... with Death' and thanking those who have come 'to bid [him] farewell' as 'he scatter[s] [himself] before' the reader, each line like a premature spreading of his own ashes (2010: 3), so does To Be Continued... open with a voice expectant of the grave. Its central focus is a spectral figure all too eerily familiar in the 'Western' cultural imaginary of Palestine: that of the Muslim Jihadist, or martyr, recording his last statement before going to his death. This is a deliberately hyperbolic image that, in its clichéd typecasting of the Palestinian as purveyor of militancy, radicalism and death, draws subtle attention to the reductive visual presentation of the Palestinian subject in international circulation. 


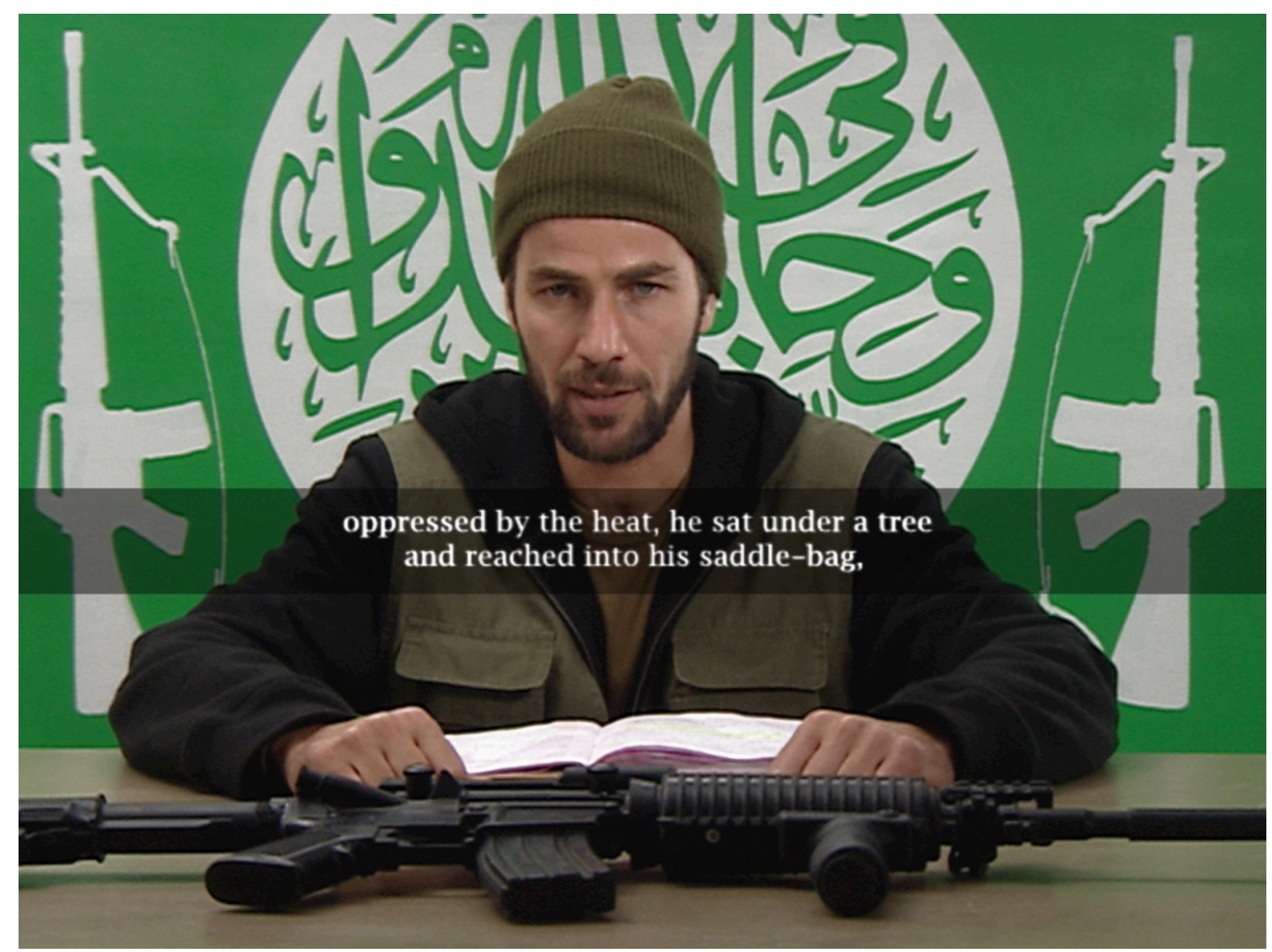

Figure 1: still from Sharif Waked, To Be Continued... (2009). Image courtesy of the artist.

Yet this is far from the whole story at work within the piece. While Waked skilfully mimics the visual signifiers of the martyr's video - the green cloth backdrop, rifle and martyr's address to the camera - there are, as Gordon Hon notes, subtle slippages from the usual visual narrative. Besides the suspiciously 'well-produced' quality of the video, 'the words [on the cloth behind the martyr] are vague platitudes and there is no recognisable organization. The 'terrorist'... is being played by the popular Palestinian actor, Saleh Bakri' (Hon 2013: 178). Most subversive of all, though, is the nature of the narrative that the martyr is recounting: not a statement of deadly intent, but rather, captivating stories of love and drama from the One Thousand and One Nights. Here, then, the 'terrorist' is playfully recast in the role of reluctant martyr, determined, like Sheherazade, to delay his own execution by spinning endlessly beguiling tales that enthral rather than alienate his audience. Thus, as Tina Sherwell notes, Waked's video work constructs 'an elaborate narrative of no conclusion...of continual delay, of postponement' (Sherwell 2013: 228), which resists the inevitable drive towards 
absence - absence of living presence, absence of narrative complexity - that initially seems to be promised by the martyr's ghoulish appearance.

The tone of Waked's work - its sinister irony, even humour - could not be more different from Darwish's own altogether more earnest, often sombre meditations on mortality and death in Absent Presence (though elsewhere, Darwish also revealed a similar taste for cynical wisecracks, once quipping that as Palestinians, 'we have no State, but we have plenty of humour'. Ben Jalloun 2008: 20). What Waked and Darwish's works share, though, is a resistance to the inevitability of the 'Death Drive' through the resistant production of language. Again and again, Darwish urges his reader to 'never think that you are dead [...] write the history of your race, from the time when you garnered from the sea her regular breathing, until you return to me, alive' (2010: 6). For Darwish, as for Waked, asserting creative control over one's own narrative therefore has the capacity to pull the storyteller or poet back from the brink of death. Elsewhere, Darwish commands his reader (who is also, implicitly, the spectral past self of Darwish's lost youth):

Become a child again; teach me poetry; teach me the rhythm of the sea; give back to words their pristine innocence... before concepts. The tall tree used to walk with us as a tree, not a concept $[\ldots]$ Take my hand so that we may cross this gap between night and dawn together, together learn the first words. (2010: 19)

Here, then, Darwish, like Waked, seeks to reverse the inevitable trajectory towards absence and erasure that has often been enforced on the Palestinian narrative, and imagines instead regressing to what might be described in psychoanalytic terms as a pre-Oedipal state of jouissance: the sense of total bliss and wholeness experienced in the early stages of pre-linguistic infancy when, according to Darwish, words have 'pristine innocence' and the world is tangible, not abstract, 'the tall tree...a tree, not a concept'. Darwish seems to find this state of bliss, and implicitly of connection with the 'innocent' Palestine of his childhood, through the incantatory and mesmerising qualities of poetic and literary language. It is Darwish, as well as Waked's martyr, who assumes the role of Sheherazade here, then, both of them seeking to beguile and enchant with their words in order to conjure the Palestinian subject as inhabitant of an Edenic state of childlike innocence and wonder, the stuff of 
fairytales, rather than of conditions of anxiety and fear. Ghoulish as their communions with death may initially seem, both Darwish and Waked therefore resist the drive towards inevitable absence in their works, in favour of asserting vivacious, imaginative languages of Palestinian visual and narrative presence. This presence reveals the complex yet intrinsic connection between collective and individual psyche for both artists, Darwish undertaking what might be described as a psychoanalytic journey of regression into a traumatic history that is both individual and collective, and Waked meanwhile seeking to undermine notions of collective homogeneity through a visual language that is at once politically and personally engaged. This presence is perhaps even more significant, though, for the universalistic sense in which it reveals the turn towards the spectral as an animating rather than nihilistic force: a means to celebrate the resilience of life-even-in-death, rather than to mourn a condition of death-in-life. $^{6}$

Wherever we travel in Darwish's Absent Presence, though, we never stray very far from the sound of 'the groaning of houses under the settlements' (2010: 85): houses that also haunt the bright and daring imagination of the artist Wafaa Yasin. Born in 1980 to a farming family in the Galilee, Yasin studied at the Bezalel Academy of Arts and Design in Jerusalem and has exhibited widely within Palestine and overseas to significant acclaim, culminating in 2008 with the award of a full tuition scholarship to study Social Practice at California College of the Arts in San Francisco, where she now lives and works. Utilising the medium of performance, Yasin's work is characterised by 'stark symbolism and corporeal discomfort' (Gerrity 2011: online) achieved through the use of her own body as the vehicle for personal and political representation. In 2008, for example, Yasin's work Aesh (Livelihood) entailed Yasin using her face to push a piece of Moroccan bread along the pavement through a busy street in Marseilles, her hands tied behind her, as a symbolic response to the testimonies of Moroccan immigrants in France and of an Iraqi prisoner aired on Al-Jazeera, here presented through a visual, physical and emotional disturbance of quotidian existence. Yasin has

\footnotetext{
${ }^{6}$ I note the complex and symbiotic relationships between political and personal, universal and national, collective and individual affiliations here because they remain a constant source of pressure for many Palestinian artists. This emerged with particular clarity during the curation of 'Presenting Absence', a number of invited artists expressing their unease at the idea of exhibiting within an exhibition of 'Palestinian art' at the risk of homogenization, and of reductive nationcentred readings of their work. Nevertheless, most invitees participated on the grounds of the overarching philosophical 'presence/absence' dialectic, which also enabled their work to be read in senses both more universalistic and more individualistic.
} 
often employed video as a means to record her performances (see also What Remains, 2009), but The Imaginary Houses of Palestine (2010) engages more consciously with the video art medium in order to create complex dialogues not only between performance and audience but also between image and text, place and body, presence and absence.

In Absent Presence, Darwish speaks of 'the imaginary houses of Palestine' that exist in his father's memory, which he 'began to build... out of...rubble... from the names of plants and minerals, so that the place should remain his place' (2010: 110). This process of rebuilding absent place through memory is strongly reminiscent of what Lila Abu-Lughod describes as the creation of 'living history' among Nakba survivors, whereby they 'insert...memories of Palestine directly into the present' as a means to find traces of that absent past within their present-day landscape (Abu-Lughod 2007: 79). Thus these houses occupy a spectral presence within the text as sites that are at once buried beneath the earth but which can also be raised from their absence through the power of memory and testimony. As such, their imaginative resurrection constitutes an important counterdiscourse to what Basem Ra'ad describes as the Israeli obsession with archaeology as a means to recover apparently scientific evidence of ancient Jewish claims to the land ( $\operatorname{Ra}$ 'ad 2010: 151). Darwish himself satirizes this discourse in an imagined exchange with a figure he terms the 'armed archaeologist' within Absent Presence:

'Who are you?'

And you felt all your limbs and said, 'I am I.'

And they said, 'What proof is there?'

And you said, 'I am the proof.'

And they said, 'That is not enough; we need a nothing.'

And you said, 'I am complete and nothing.'

And they said, 'Say you are a stone so that we may finish excavation.'

And you said to them, 'If only a young man were a stone.'

And they did not understand you. (2010: 6) 
In Wafaa Yasin's 7-minute split-screen video work, 'The Imaginary Houses of Palestine', it is precisely the assertion that a person can assume the solidity of stone, the presence of place, which is at stake. This work, which was inspired in part by the artist's own reading of Darwish's Absent Presence, consists of two recordings of site-based performances overlaid with an audio narrative. The first performance takes place in an old abandoned factory in San Francisco (the city to which Yasin moved in adulthood, having been raised in the Galilee), the tiles of which reminded her of the ornate tiling patterns evident in old Arab houses in Jerusalem. The second performance takes place in an abandoned construction site also in San Francisco, which for Yasin, called to mind the excavated sites in Silwan, East Jerusalem, where settlers and archaeologists have, with the support of the Israeli government, been looking for evidence of a biblical village beneath Arab houses, which eventually causes them to collapse. In both of these performances, Yasin undertakes tasks from everyday life that involve caring for or restoring these sites: in the first, she cleans and grouts the tiles of the factory, while in the second, she washes the foundations of the building.

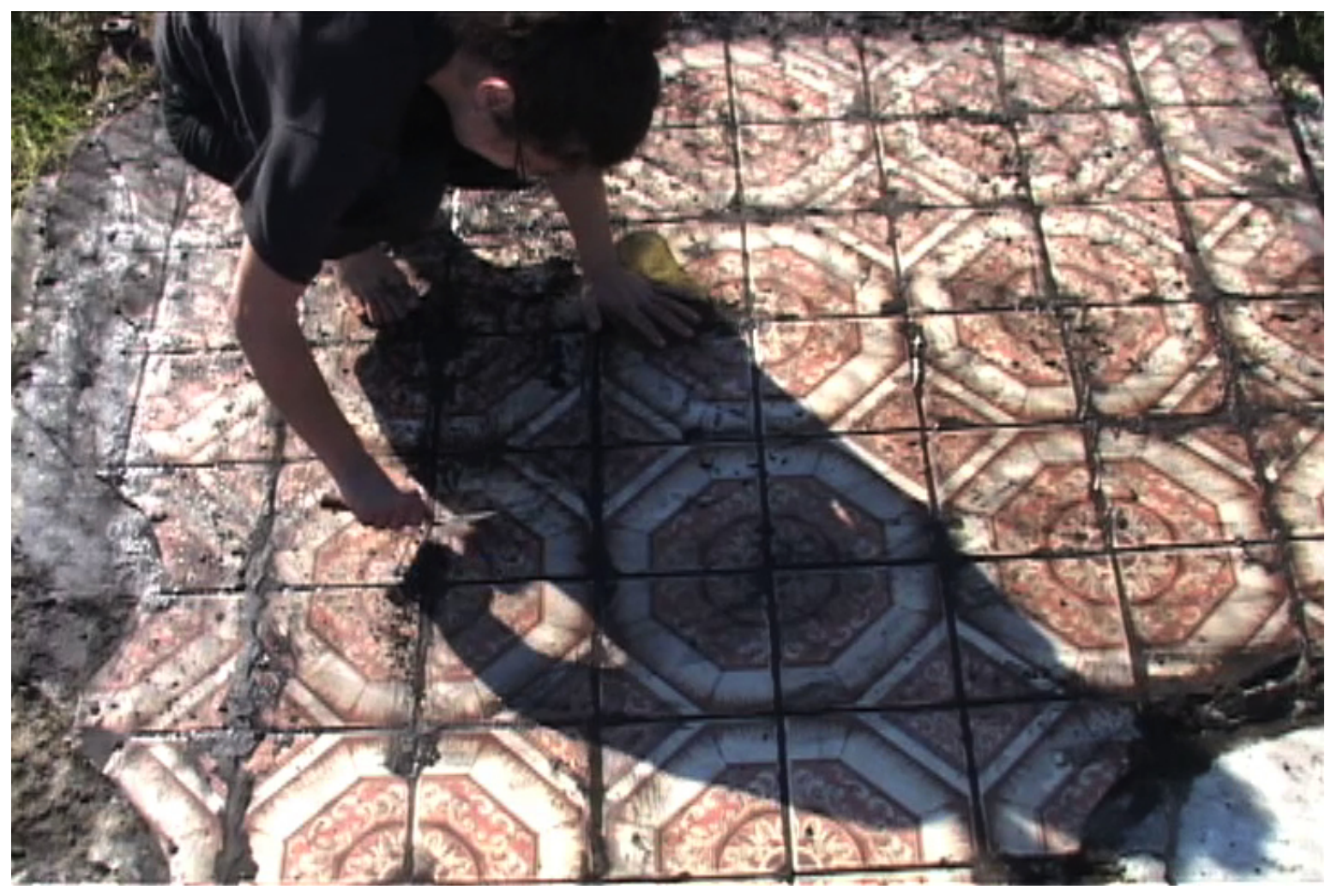

Figure 2: still from Wafaa Yasin, The Imaginary Houses of Palestine (2010). Image courtesy of the artist. 
As such, she enacts an everyday language of care and regeneration that powerfully defies the destruction of Palestinian place, reminiscent of Darwish's declaration in Absent Presence that 'I will sow the seeds of violets on these two yards, and water them, so that nothingness will rouse itself and pass far away' (2010: 121). Similar to the way in which the growth of cacti plants renders visible the perimeters of destroyed Palestinian villages, landscape itself bears regenerative properties for Darwish and Yasin, presence inevitably blooming out of absence.

Crucially, however, both performances are overlaid with an audio recording of Yasin standing within and describing an old, abandoned house in Jerusalem, usually closed to public access. Though this house remains invisible to us, Yasin describes the house in such vivid detail that it assumes an almost tangible presence, the 'old lemon tree in the courtyard' sprouting through one's imagination within the old factory we see on the screen. The highly sensuous nature of Yasin's description bears parallels with Darwish's own observation that 'places of exile have a smell in common, a smell of longing for something else... an emotion which leads you...to the smell of the first place' - whether to a 'Cairo [that] smells of mango and ginger'; a 'Haifa [that] smells of pinewood and crumpled bedsheets' or a 'Damascus [that] smells of jasmine and dried fruits' (Darwish 2010: 60). For Yasin, too, vivid sensual recollection means that an absent place comes to assume a spectral, palimpsestic presence through her own bodily experiences and their recollection, echoing Darwish's observation in Absent Presence that "memory... admits you to the contents of what is lost, to a sesame field, to a bed of lettuce and mint...The loss grows within you' (2010: 61). It is possible to read this layering of absent place upon the present as a reflection of the quintessential sense in which, as Steiner puts it, exiles are 'poets unhoused...wanderers across language' (Steiner quoted in Said 2001: 173). Certainly, the spectral presence of absent place within Yasin's work bears clear parallels with Said's concept of 'contrapuntal consciousness' whereby, 'for an exile, habits of life, expression, or activity in the new environment inevitably occur against the memory of these things in another environment' (Said 2001: 186). Yet Yasin's particular use of the video art medium suggests a less ready reconciliation to her liminal positioning between presence and absence. Yasin's use of split-screen image and of mirror-image text echoing the audio narrative creates a sense of simultaneity within the 
work that is suggestive of an unsettling doubling and repetition of place and time, rather than simply of 'contrapuntal consciousness'. The effect of such doubling is in fact to evoke a much stronger sense of the 'uncanny', literally the 'unheimlich' or 'unhomely', described by Bennett and Royle as 'a kind of ghost-effect that haunts all words, however..."familiar" they appear to be' (2004: 40). Similarly, the 'imaginary houses of Palestine' are never presented as either securely familiar or unfamiliar in Yasin's work, and Yasin herself appears a somewhat incongruous, even ghostly figure, 'out of time' (as well as out of place) within the dilapidated, abandoned buildings that she curates.

While Yasin's resurrection of an absent place through her own memory and body can therefore be read as deeply connective between the diasporic Palestinian and the lost homeland, it is also indicative of the traumatic nature of what Abu-Lughod, following Marianne Hirsch, terms 'postmemory', whereby 'one's everyday reality [is] overshadowed by the memory of a much more significant past that one's parents lived through' (Abu-Lughod 2007: 79). Yasin is haunted by more than her own memories of the abandoned houses in Jerusalem and Silwan in this work, then; the potent political symbolism of her performances also invokes the spectre of the Nakba, rendering Yasin the restless guardian of a much larger collective history of loss and disenfranchisement. In The Imaginary Houses of Palestine, she becomes a figure who is, according to Darwish, 'both the mourner and the one mourned for' (2010: 7) - but it is also through her actions, which are designed not simply to mourn but also to heal, that 'the shape of love becomes manifest, in an absence dense with presence' (Darwish 2010: 89).

Placing Darwish's Absent Presence in conversation with Waked's To Be Continued... and Yasin's The Imaginary Houses of Palestine reveals the presence of many talkative ghosts: of lost childhood and innocence; of absent homeland and historical trauma; of a nation haunted by decades of reductive, hyperbolic visual misrepresentation of Palestine and Palestinians. Yet as Yasin's work affirms, it is not a vengeful ghost that arises from this dialogue between presence and absence; rather, the spirit of that which lies at the very heart of the relationship between deceased and mourner, art and artist, place and memory, Palestine and its people: love. Whether in the form of Waked's silvertongued martyr recounting tales of romance, in the quiet care of Yasin's scrubbing hands determined 
to find traces of her past in the present or in Darwish's own nostalgic and desirous memories of homeland and of lovers, love surfaces in these works as a spirit that lifts the Palestinian moving image above a negative politics of perpetual erasure and anti-representation, revealing instead the inextricable connectedness of collective and individual, past and present, present and absent in the creative imagination. Ultimately, then, the presence of the spectral emerges as an animating rather than deadening force within these works and it is significant, therefore, that Derrida should also view the spectre not as a figure trapped in the past. In its insistence on a 'desire of resurrection', on inevitable and unstoppable return and on the inevitability of their being witnessed within both the present and the future, the figure of the spectre suggests to Derrida that in fact, 'the future can only be for ghosts' (1994: 36-37). Darwish takes this even further and commands his reader: 'Do not look upon yourself in the way they write about you. Do not investigate the Canaanite in you in order to establish that you exist. Rather, seize this reality, this name of yours, and learn how to write your proof. For you are you, not your ghost...' (2010: 22).

The ghosts that appear to us in Absent Presence therefore gesture not towards what is lost but to what remains present in the face of absence. In Darwish's gentle yet strident tone, they speak hauntingly of a 'right to return' in order to 'write their proof' into past, present and future alike. Though drawing on very different aesthetic strategies, Waked and Yasin also animate this spirit within their own work, using the video art medium to imagine, record and (re)present their own conversations with the absence/presence dialectic in a way that ultimately enables them to follow Darwish's command and 'write their proof': proof both of a vital connection to a past that refuses to absent itself quietly, and to a vibrant creative present that they have themselves set in motion.

\section{References}

Abu-Lughod, Lila. (2007) Return to Half-Ruins: Memory, Postmemory and Living History in Palestine. In Lila Abu-Lughod and Ahmad H. Sa'di (eds.), Nakba: Palestine, 1948, and the Claims of Memory, pp.77-106. New York: Columbia University Press. 
Ahmed, Hamoud Yahya; Ruzy Suliza Hashim; Zalina Mohd. Lazim and Ravichandran

Vengadasmy. (2012) Identity and Land in Mahmoud Darwish’s Selected Poems: An Ecopostcolonial Reading. International Journal of Applied Linguistics and English Literature. 1(6): 7-19.

Al Azzeh, Dia’. (2009) Motionless Weight. Video art, 4 minutes, 19 seconds.

Alshaer, Atef. (2013) Humanism, Nationalism and Violence in Mahmoud Darwish's Poetry. In Hugh Kennedy (ed.), Warfare and Poetry in the Middle East, pp.257-283. London: I.B.Tauris.

Al-Rahbi, Saif. (2008) The Theme of Absence. Banipal. 33: 60-62.

Antoon, Sinan. (2008) An Entourage of Violins and Clouds. Banipal. 33(5): 4-5.

Ben Jelloun, Tahar. (2008) Mahmoud Darwish is Dead. Long live his poetry! Banipal. 33: 20-22.

Bennett, Andrew and Nicholas Royle. (2004) Introduction to Literature, Criticism and Theory. London: Longman.

Bernard, Anna and Ziad Elmarsafy. (2002) Intimacies: In Memoriam Mahmoud Darwish. Interventions. 14(1): 1-12.

Bitton, Simone (dir). (1998) As the Land is the Language. Israel / France: Point du Jour International. Dabashi, Hamid (ed). (2006) Dreams of a Nation: On Palestinian Cinema. London: Verso. Darwish, Mahmoud. (1980) [1960 in Arabic] Identity Card. In The Music of Human Flesh. Translated from the Arabic by Denys Johnson-Davies, pp.10-11. London: Heinemann. (2003) Mural. In Unfortunately, It Was Paradise. Translated from Arabic by M. Akash and C. Forché, pp.117-162. Berkeley: University of California Press. (2007). The Butterfly's Burden. Translated from Arabic by Fady Joudah. Tarset:

Bloodaxe. (2010) [2006 in Arabic] Absent Presence. Translated from Arabic by Mohammad Shaheen. London: Hesperus Press.

Derrida, Jacques. (1994) Spectres of Marx: The State of the Debt, the Work of Mourning and the New International. Translated from French by Peggy Kamuf. New York: Routledge. 
Freud, Sigmund. (1909) Analysis of a Phobia in a Five-Year-Old Boy. In The Standard Edition of the Complete Works of Sigmund Freud Volume X. Translated from German by James Strachey. London: Vintage.

Gerrity, Jeanne. (2011) Performing the Personal and Political: The Art of Wafaa Yasin. Art Practical. $4(22)$ :

http://www.artpractical.com/feature/performing_the_personal_and_political_the_art_of_wafa a $\_$yasin/. Accessed $13^{\text {th }}$ February 2014.

Godard, Jean-Luc (dir). (2004) Notre Musique. France / Switzerland: Avventura Films.

Hamdi, Tahrir. (2011) Bearing Witness in Palestinian Resistance Literature. Race and Class. 52(3): 21-42.

Hanafi, Sari. (2002) Opening the Debate on the Right of Return. Middle East Report. 222: 2-7. Hochberg, Gil. (2010) 'Check Me Out': Queer Encounters in Sharif Waked's Chic Point: Fashion for Israeli Checkpoints. GLQ: A Journal of Lesbian and Gay Studies. 16(4): 577-597.

Hon, Gordon. (2013) Blessed Oblivion: Palestinian Video Art and the Avant-Doc. In Bashir Makhoul (ed.), Palestinian Video Art: Constellation of the Moving Image, pp.172-187. Jerusalem: Palestinian Art Court - al Hoash.

Jacir, Annemarie. (2006) 'For Cultural Purposes Only’: Curating a Palestinian Film Festival. In Hamid Dabashi (ed.), Dreams of a Nation: On Palestinian Cinema. London: Verso.

Jayyusi, Lena. (2007) Iterability, Cumulativity, and Presence: The Relational Figures of Palestinian Memory. In Lila Abu-Lughod and Ahmad H. Sa'di (eds.), Nakba: Palestine, 1948, and the Claims of Memory, pp.107-134. New York: Columbia University Press.

Magagnolio, Paulo. (2011) A Method in Madness: Historical Truth in Walid Raad's The Bachar Tapes. Third Text. 25(3): 311-324.

Makhoul, Bashir. (2013) Palestinian Video Art: Constellation of the Moving Image. Jerusalem: Palestinian Art Court - al Hoash.

Masri, Mai (dir). (2001) Frontiers of Dreams and Fears. Seattle: Arab Film Distribution. 
Masalha, Nur. (2012) The Palestinian Nakba: Decolonising History, Narrating the Subaltern,

Reclaiming Memory. London: Zed Books.

Meir, Golda. (1969) The Sunday Times. $15^{\text {th }}$ June.

Natche, Ahmed (dir). (2012) Two Metres of This Land. Palestine: Turab Films.

Ra'ad, Basem. (2010) Hidden Histories: Palestine and the Eastern Mediterranean. London: Pluto.

Rothberg, Michael. (2008) Decolonizing Trauma Studies: A Response. Studies in the Novel. 40(1/2): 224-234.

Said, Edward with photographs by Jean Mohr. (1986) After the Last Sky: Palestinian Lives. New York: Pantheon.

Said, Edward. (1992) The Question of Palestine. London: Vintage.

-. (2001) Reflections on Exile. In Reflections on Exile and Other Literary and Cultural Essays, pp.173-186. London: Granta Books, 2001.

Schechla, David. (2001) The Invisible People Come to Light: Israel's 'Internally Displaced' and the 'Unrecognized Villages'. Journal of Palestine Studies. 31(1): 21-22.

Shehadeh, Raja. (2002) Interview with Mahmoud Darwish. Bomb. 81: 54-59.

Sherwell, Tina. (2013) Time's Loop: Contemplations on Palestinian Video Art. In Bashir Makhoul (ed.), Palestinian Video Art: Constellation of the Moving Image, pp.216-233. Jerusalem: Palestinian Art Court - al Hoash.

Suleiman, Elia (dir). (2002) Divine Intervention. France / Germany / Morocco / Palestine: Pyramide Distribution.

Visser, Irene. (2011) Trauma Theory and Postcolonial Literary Studies. Journal of Postcolonial Writing. 47(3): 270-282.

Waked, Sharif. (2002) Jericho First. Graphic design and site-specific installation, Hagar Art Gallery, Jaffa.

(2008) Khumus. Sculptiure and site-specific installation, Ayn Hawd, near Haifa. (2009) To Be Continued... Video art, 41 minutes.

Yasin, Wafaa. (2008) Aesh. Video performance, 45 minutes. 
(2009) What Remains. Video performance, 13 minutes.

(2010) The Imaginary Houses of Palestine. Video art, 7 minutes.

\section{Biographical details}

Anna Ball is Senior Lecturer in the Department of English and Media Studies at Nottingham Trent University, where she also co-directs the Centre for Colonial and Postcolonial Studies. Recent publications include her monograph, Palestinian Literature and Film in Postcolonial Feminist Perspective (Routledge, 2012); a special issue of the Journal of Postcolonial Writing on 'Palestine and the Postcolonial' (co-edited with Patrick Williams, 2014: 15(2)); and a number of articles exploring gender, space and mobility in literary and visual work from the Middle East, which have appeared in journals including Camera Obscura, Cultural Research and the Journal of Postcolonial Writing. She is also actively involved in the visual arts, and in September 2013, curated an exhibition of Palestinian short film and video art entitled 'Presenting Absence: Moving Images of Palestine' at the Bonington Gallery, Nottingham Trent University; while in October-November 2013, she coorganized (with Karim Mattar) the first Oxford Palestine Film Season (www.oxpalfilmseason.org.uk). She is currently working on a new monograph, The Body in Flight, which explores the relationship between embodiment, politics and mobility in the postcolonial imagination. 